\title{
DISCURSO DE ÓDIO E REGRA DE DECISÃO: UM ESTUDO SOBRE A JURISPRUDÊNCIA DA CORTE EUROPEIA DE DIRETOS HUMANOS E DA CORTE INTERAMERICANA DE DIREITOS HUMANOS
}

\section{Marcelo Garcia da Cunha ${ }^{1}$}

RESUMO: O estudo tem por objeto a análise da problemática que envolve o discurso de ódio e o seu nível de permissibilidade nos sistemas de proteção de direitos humanos europeu e interamericano. A apreensão do critério decisório aplicado pelos tribunais na resolutividade das situações que envolvem o discurso de ódio permite uma adequada avaliação dos respectivos limites de expressão. Percebe-se, no cotejo entre as regras decisórias, uma clara identidade entre os critérios aplicados pela Corte Europeia e pela Corte Interamericana, que se estende inclusive ao nível de admissibilidade ao discurso de ódio, que, em ambas as jurisdições, é bastante limitado.

Palavras-chave: Discurso; Ódio; Jurisprudência; Regra Decisória; Nível de Admissibilidade.

\section{HATE SPEECH AND DECISION RULE:}

\section{A STUDY ON THE JURISPRUDENCE OF THE EUROPEAN COURT OF HUMAN RIGHTS AND THE INTER-AMERICAN COURT OF HUMAN RIGHTS}

\begin{abstract}
The purpose of this study is to analyze the problem of hate speech and its level of permissibility in European and inter-American human rights protection systems. The apprehension of the decision-making criterion applied by the courts in the resolution of the situations involving the hate speech allows an adequate evaluation of the respective limits of expression. In the comparison between the rules of decision-making, a clear identity is identified between the criteria applied by the European Court and the Inter-American Court, which extends even to the level of admissibility to the hate speech, which in both jurisdictions is quite limited.
\end{abstract}

Keywords: Speech; Hate; Jurisprudence; Rule of Decision; Level of Admissibility.

\footnotetext{
1 Pós-Doutor pela Universidade de Santiago de Compostela. Doutor e Mestre em Direito pela PUCRS. Advogado. Endereço postal: rua Andrade Neves, 155/116, bairro Centro, Porto Alegre/RS - CEP 90010-210. Endereço eletrônico: marcelogdacunha@ hotmail.com
} 


\section{INTRODUÇÃO}

O estudo tem por objeto a análise da problemática que envolve o discurso de ódio e o seu nível de permissibilidade no âmbito dos sistemas de proteção de direitos humanos europeu e interamericano.

A apreensão do critério decisório comumentemente aplicado pelos tribunais na resolutividade das situações que envolvem o discurso de ódio permite uma adequada avaliação dos limites de expressão adotados em regiões diversas. Embora os tensionamentos resultantes dessa prática discursiva tenham dimensões assimétricas, pois dependem das cambiantes realidades locais, o núcleo do debate jurídico apresenta certa simetria, em razão do fato de que o direito à liberdade de expressão é tutelado na normatização das sociedades democráticas.

O objetivo, aqui, numa perspectiva comparativa, é identificar a regra decisória aplicada em diferentes jurisdições transnacionais e apontar os pressupostos fático-jurídicos que ensejam sua incidência. O cotejo entre uma e outra será inevitável e indicará o respectivo nível de admissibilidade ao discurso de ódio.

A abordagem dos critérios de decisão passa pelo estudo da casuística jurisprudencial da Corte Europeia de Direitos Humanos e da Corte Interamericana de Direitos Humanos.

A escolha das duas Cortes transnacionais se dá pela sua condição proeminente no cenário jurídico europeu e interamericano, o que lhes confere a capacidade de orientar persuasivamente a resolutividade interna das questões que emergem das manifestações de ódio.

Para alcançar os propósitos almejados, inicialmente se faz necessária uma abordagem do discurso de ódio e seu objeto, como meio de melhor realçar seus elementos tipificadores.

\section{O DISCURSO DE ÓDIO E SEU OBJETO}

Numa escola feminina administrada por duas professoras, localizada numa pequena comunidade de hábitos tradicionais, uma das alunas, em ato vingativo e dissimulado, adulterando a realidade dos fatos para sua avó, diz a ela que as professoras mantêm um relacionamento homoafetivo. A "notícia", disseminada destemperadamente pela cidade, leva à retirada de todas as crianças da escola por seus respectivos pais. A temática abordada no filme Infâmia, protagonizado por Audrey Hepburn e Shirley Maclaine em 1961, coloca em questão o 
quanto uma afirmação propalada como regra moral, incitando a aversão e a repugnância a certos indivíduos, pode se tornar uma "verdade" com efeitos nocivos ao convívio social.

Para redigir sua obra sobre a tolerância, Voltaire (2017) teve em consideração o suplício infligido a Jean Calas, por ordem da justiça francesa, sob a imputação de ter assassinado seu próprio filho, Marc-Antoine. Ao tomar conhecimento do fato, o povo se reuniu diante da casa de Calas, que era protestante, pronto para incriminá-lo. Após o primeiro grito de que havia enforcado o filho, outros se seguiram no mesmo sentido até essa acusação se tornar uníssona entre a multidão. Somente tardiamente a injustiça foi reconhecida.

John Stuart Mill (2017, p. 86), ao escrever uma das obras sagradas do liberalismo, apregoava a complacência como ideia elementar para a vida em sociedade: "A humanidade terá mais a ganhar com a mútua tolerância para que cada um viva de acordo com o que lhe parece melhor para si mesmo do que impondo a cada um que viva como parece melhor a todos os outros". Ele partia de um pressuposto que considerava muito simples no desenvolvimento de seu pensamento. Para ele, a única justificativa para qualquer interferência na liberdade individual seria aquela destinada a evitar danos a terceiros. "Sobre si mesmo", sentenciava o autor britânico, "seu próprio corpo e sua mente, o indivíduo é soberano" (MILL, 2017, p. 82).

$\mathrm{O}$ equacionamento entre a tolerância e a liberdade talvez seja um dos grandes desafios que se impõem ao homem desde seus primeiros passos destinados à civilização às margens do Mediterrâneo. E o discurso ${ }^{2}$ de ódio, pela sua gravidade deontológica, rompe qualquer possibilidade de se promover uma composição dessa problemática.

$\mathrm{Na}$ psicologia, reconhece-se o ódio como algo inerente à condição humana (ROSSATTO; GUARDI, 2017, p. 13). Como o homem é integrado por suas virtudes e também por seus defeitos, o ódio encontra-se arraigado em seu íntimo, sendo impossível eliminá-lo. Enquanto situado no âmbito meramente reflexivo do indivíduo, nada há o que se possa fazer, mas apenas quando o ódio se exterioriza é que passa a ser problematizado social e juridicamente. E a vida pós-moderna facilita os meios para sua emergência externa.

$\mathrm{Na}$ contemporaneidade, o sujeito reivindica o seu direito de saciar seus desejos, estimulado pela incitação generalizada ao consumo desmedido. Preso a suas limitações materiais e destituído de valores absolutos, o indivíduo move-se em direção a aquilo que odeia, causa de suas frustrações. Impelido por seu ódio, esforça-se para destruir a fonte de sua repulsa

\footnotetext{
${ }^{2}$ Aristóteles (2007, p. 63), originalmente, já apontava os três elementos da atividade discursiva: sujeito, objeto e
} 
(ROSSATTO e GUARDI, 2017, p. 13).

Nesse sentido, a Recomendação Geral n. 15, relativa à luta contra o discurso de ódio e memorandum explicativo, adotada em 08 de dezembro de 2015, da Comissão Europeia contra o Racismo e a Intolerância, considera que o termo ódio está relacionado a emoções intensas e irracionais de desprezo, inimizade e aversão. A Recomendação entende por discurso de ódio o uso de uma ou mais formas de expressão, baseada em características pessoais que incluem raça, cor, idioma, religião ou crenças, nacionalidade ou origem nacional ou étnica, ascendência, idade, incapacidade, sexo, gênero, identidade de gênero e orientação sexual.

A Recomendação adverte que o discurso de ódio pode revelar-se de formas muito diversificadas, exteriorizando-se mediante verbalização ou meio escrito, além de qualquer outra forma como pintura, sinais, símbolos, música, obras de teatro e vídeos. Também pode expressar-se através de gesticulação, opinião e pelos diversos veículos de comunicação. $\mathrm{Na}$ Espanha, o Tribunal Constitucional, na Sentença 177/2015, decidiu que a queima pública de retrato dos Monarcas é um ato ofensivo e incitador ao ódio, pois a cremação da imagem física expressa a ideia de que os Reis são merecedores de exclusão e repulsa.

O ódio pode se concretizar também por uma "linguagem codificada". Na Europa, neonazistas e nacionalistas agressivos apregoam que há gente que não trabalha e vive de subsídios estatais, ao passo que nos Estados Unidos conservadores que se intitulam patrióticos atribuem aos hispanos-americanos os males da sociedade estadunidense. Subjacente a essa retórica discursiva está a ideia de que há sujeitos inferiores comparativamente a outros, integrantes da parcela ruim da sociedade e que por esse motivo devem ser banidos do convívio social.

A lógica maniqueísta do "bom" (emissor do discurso) contra o "mau" (características e ideias do opositor) move a retórica de ódio, incitando a audiência a aniquilar aqueles que representam um perigo a princípios e valores considerados superiores ou absolutos (SILVA; FAVERA, 2017, p. 286).

Desde 1965, a Convenção Internacional sobre a Eliminação de Todas as Formas de Discriminação Racial, da Assembleia Geral das Nações Unidas, conclama a comunidade global a condenar a promoção de ideias baseadas na superioridade de uma raça ou de um grupo de indivíduos de determinada cor ou origem étnica, capazes de gerar sentimentos de ódio e de 
discriminação. Tal como assinalado no caso Ellwanger, no Habeas Corpus 82.424-2/RS, decidido pelo Supremo Tribunal Federal, envolvendo publicação de obra escrita com ideias anti-semitas, com a definição e o mapeamento do genoma humano cientificamente restou comprovado que inexistem distinções entre os seres humanos, seja pela segmentação da pele, formato dos olhos, altura ou quaisquer outras características físicas. A ausência de diferenças biológicas confere a todos o traço essencial da igualdade.

Até mesmo o silêncio pode ser discriminatório. A depender das circunstâncias, a desconsideração ou a negação da presença do outro constitui forma igualmente perniciosa de atingir o mesmo efeito que seria produzido por qualquer outro meio ativo de expressão.

O ódio ocasiona danos no íntimo dos homens e nos espaços públicos, notadamente produz efeitos na esfera subjetiva das pessoas as quais é direcionado e de uma forma contextualizada e objetiva atinge a higidez da sociedade.

Como constitui uma violência, o discurso de ódio é capaz de lesionar a integridade psicofísica do indivíduo ou mesmo do grupo social visado. As qualidades personalísticas descritas no discurso de ódio (raça, etnia, nacionalidade, gênero, orientação sexual, crença, etc.) permitem a auto-identificação dos destinatários. A ofensa percebida atinge a dignidade e o senso de pertencimento e aceitabilidade pessoal no cenário social, podendo causar efeitos devastadores no estado anímico do indivíduo.

Em certa passagem de sua cinebiografia, Harvey Milk, ativista dos direitos civis nos anos 1970 na costa oeste dos Estados Unidos, relata que teve quatro relações afetivas, sendo que três de seus ex-companheiros tentaram o suicídio porque o relacionamento entre eles não podia ser assumido publicamente, devido ao preconceito generalizado que à época reinava na sociedade norte-americana.

Em um amplo estudo acerca dos efeitos psicológicos dos crimes de ódio, Inta Dzelme (2008, p. 11) refere que, ao atacar a identidade do indivíduo, essa espécie de violência causa danos emocionais e psíquicos, como sentimento de medo, sensação de vulnerabilidade social, raiva, depressão, dificuldades cognitivas e de relacionamento interpessoal e mesmo, em casos mais graves, pensamentos suicidas, além de efeitos de caráter psicossomático, como aceleração ou desaceleração cardíaca, distúrbios gástricos, modificações nas atividades glandulares, tremores, náuseas.

Para Dzelme (2008, p. 08), o delito de ódio implica uma grave violação do princípio da equidade, inerente ao Estado Democrático Constitucional, porque atinge a essência da pessoa, 
a sua alma, mais especificamente quem ela é.

Nesse estado de fragilização, a vítima experimenta uma sensação de injustiça e de descrédito em relação a instituições estruturantes da sociedade, como a lei e o sistema de proteção judicial, percebidos como ineficazes e inoperantes frente à agressão sofrida, podendo inclusive segregar-se e afastar-se dos valores fundantes da sociedade em que vive.

Não apenas o impacto subjetivo do discurso de ódio interessa ao direito, mas igualmente seus efeitos danosos à coesão social.

A retórica da intolerância implica uma ideia de exclusão por parte daqueles a quem ela é direcionada. Esse sentimento gerado pelo ódio produz fragmentação na sociedade, pois, assim como sucede no âmbito das individualidades afetadas, leva ao sentimento de rejeição dos estratos sociais atingidos.

O mais grave, contudo, sob esse ponto de vista da problemática do discurso de ódio, é o incitamento de outras pessoas a cometerem ações de violência, intimidação, hostilidade e discriminação contra aqueles a quem é dirigido. Ainda que esses atos não sejam levados a efeito de imediato, a ênfase discursiva na intolerância poderá produzir esse resultado em um futuro próximo, rompendo os alicerces da convivência social. A agressão pode gerar inclusive uma reação equivalente, dando margem a um contexto de retaliação entre grupos (DZELME, 2008, p. 14).

Do exame in concreto dos casos envolvendo discurso de ódio, frequentemente emerge a contraposição entre o direito à liberdade de expressão e o direito à integridade moral. A forma como vem sendo equacionada essa questão pela jurisdição europeia será objeto de abordagem na sequência deste texto.

\section{REGRA DECISÓRIA APLICADA PELA CORTE EUROPEIA DE DIREITOS HUMANOS}

Ela foi uma presença transformadora em um mundo pertencente aos homens, o que a levava inclusive a vestir roupas masculinas, em que pese a maioria deles não tomasse a sério suas ações. Ela ouvia vozes e as atribuía a Deus. Para o Clero, contudo, as palavras divinas eram privilégio da Igreja. Como herege, Joana D’Arc deveria queimar na fogueira e assim foi feito.

A Europa da contemporaneidade, do diálogo intercultural, que guia as relações entre 
seus povos, é muito diversa da época em que os corpos ardiam no fogo. O continente se destaca no cenário global pela primazia conferida aos direitos humanos, perenizados nas Constituições nacionais e em documento convencional direcionado à tutela supranacional de tais direitos ${ }^{3}$.

Nesse processo de consolidação da liberdade e dos direitos do cidadão europeu, assume relevância a Convenção para a Proteção dos Direitos do Homem e das Liberdades Fundamentais, firmada em Roma em 04 de novembro de 1950.

Como expressa seu próprio título, o tema da liberdade ocupa espaço essencial no âmbito da Convenção.

$\mathrm{O}$ art. $5^{\circ}, \S 1^{\circ}$, de maneira geral, consigna que toda pessoa tem direito à liberdade e segurança. $\mathrm{O}$ art. $9^{\circ}, \S 1^{\circ}$, tutela o direito à liberdade de pensamento, de consciência e religião, ao passo que o $\$ 2^{\circ}$ garante a liberdade de manifestar convicções sem restrições de qualquer espécie, ressalvadas aquelas que, nos termos da lei dos Estados, sejam necessárias, numa sociedade democrática, à segurança pública, à proteção da ordem, da saúde e da moral públicas, ou à proteção dos direitos e liberdades de outrem. $\mathrm{O}$ art. 10 , no seu $\S 1^{\circ}$, assegura o direito à liberdade de expressão, compreendendo a liberdade de opinião e a liberdade de receber ou transmitir informações ou ideias sem ingerência das autoridades públicas. O mesmo dispositivo convencional, no seu $\S 2^{\circ}$, autoriza que a liberdade de expressão seja submetida a certas formalidades, condições, restrições ou sanções previstas pela lei, que constituam cautelas necessárias, numa sociedade democrática, para a segurança nacional, a integridade territorial ou a segurança pública, a defesa da ordem e a prevenção do crime, a proteção da saúde ou da moral, a proteção da honra ou dos direitos de outrem, para impedir a divulgação de informações confidenciais, ou para garantir a autoridade e a imparcialidade do poder judicial.

A Corte Europeia de Direitos Humanos vem sistematicamente aplicando, nos casos envolvendo manifestações discursivas de ódio, como critério decisório, a norma extraída dos arts. $9^{\circ}$ e 10 da Convenção, notadamente aquela que autoriza restrições à liberdade de expressão somente quando revelar-se medida necessária à higidez de uma sociedade democrática.

\footnotetext{
${ }^{3}$ Roberto Blanco Valdés (2010) narra de forma definitiva todo o percurso do constitucionalismo europeu, originário das Revoluções Liberais, que destruíram as monarquias absolutas e impulsionaram um processo de agregação de poder nas mãos do Estado Constitucional.
} 
No caso Jersild v. Denmark (15890/89), a jurisdição nacional havia condenado o demandante por ter contribuído, no exercício de sua atividade de jornalista, para a disseminação de declarações racistas feitas por terceiro durante uma entrevista.

Para a Corte, a condenação de profissional de imprensa prejudicava a possibilidade de discussão acerca de questões de interesse público. As razões aduzidas na decisão condenatória, amparadas na necessidade de proteção de direitos e da reputação de terceiros, não se mostravam suficientes para se admitir interferência na liberdade de expressão. A desproporcionalidade do meio empregado para a tutela de direitos implicou, conforme entendimento do Tribunal Europeu, violação ao disposto no art. 10 da Convenção.

Para a Corte Europeia, a liberdade de expressão constitui um dos fundamentos essenciais de uma sociedade democrática e, por isso, condição básica para seu progresso e para o desenvolvimento individual de seus cidadãos. Essa liberdade deve ser observada não apenas quando as informações ou ideias são bem recebidas pela comunhão social ou quando são consideradas inofensivas, mas também cumpre ser assegurada até mesmo quando causam indignação, perplexidade e insatisfação. Trata-se de consequência do pluralismo e da tolerância, sem os quais a democracia resta inviabilizada.

Sürek, cidadão turco, era sócio majoritário de uma revista semanal publicada em Istambul. Na edição de agosto de 1992, foram publicadas cartas de dois leitores, cujo conteúdo foi considerado pelas autoridades nacionais violador da indivisibilidade nacional e indutor de ódio entre as pessoas, visto que, ao enaltecerem o movimento de independência do Curdistão, faziam apologia de ideias separatistas, ameaçando a integridade do Estado e a unidade da nação.

Em análise ao caso Sürek v. Turkey (26682/95), o Tribunal Europeu consignou que as restrições à liberdade de expressão devem ser construídas de forma estrita, considerando que a necessidade de ingerência a esse direito, conforme previsto no art. 10, §2 $2^{\circ}$, da Convenção, pressupõe uma necessidade social imperiosa, a ser aferida à vista do contexto circunstancial do caso, de modo a se alcançar uma adequada conclusão a respeito da proporcionalidade das medidas e da relevância e suficiência das razões para interferência pela autoridade estatal. Como a região do Curdistão apresentava sérios distúrbios sociais, ao custo de muitas perdas humanas, a Corte entendeu que o conteúdo das cartas glorificava a violência e configurava discurso de ódio, sendo, por isso, legítima a decisão das autoridades turcas.

Aplicando a mesma regra de que a interferência na liberdade de expressão deve 
configurar uma necessidade social imperiosa, a Corte Europeia decidiu de maneira diversa no caso Otegi Mondragón v. Spain (2034/07), considerando que houve infringência ao art. 10 da Convenção.

Em 2003, Mondragón, integrante de um grupo parlamentar da esquerda independentista do Parlamento da Comunidade Autônoma do País Vasco, afirmou à imprensa que o Rei espanhol, à época em visita na região, era chefe de um regime que impunha tortura e violência ao povo. Ele se referia à detenção, ocorrida alguns dias antes, de pessoas ligadas a uma publicação diária, por supostos vínculos com o ETA, e que afirmaram que sofreram maus tratos durante o tempo em que ficaram detidas. Em razão de suas declarações, Mondragón foi condenado por injúria grave ao Rei pela jurisdição espanhola.

O Tribunal entendeu que a restrição ao direito do requerente não se enquadrava ao padrão decisório da necessidade social imperiosa, visto que, analisado o contexto dos fatos, constatava-se que as declarações se inseriam em um debate político envolvendo interesse público, sem incitação à violência e sem expressão de ódio. Em razão disso, as autoridades nacionais não empregaram, à luz do art. 10 da Convenção, uma apreciação fática aceitável.

A tutela da expressão no âmbito do debate político, por envolver de forma singular interesse público, ganha inclusive contornos mais rigorosos por parte do Tribunal Europeu, haja vista os benefícios que dela resultam para a sociedade.

O caso Morice v. France (29369/10) é ilustrativo acerca dessa afirmação.

O demandante foi condenado pela Justiça francesa por difamação a dois magistrados encarregados de atuar no processo investigatório da morte do juiz Bernard Borrel, em 1995, e que foram removidos do caso. Morice, advogado da viúva de Borrel, criticou a conduta dos juízes por considerá-la absolutamente incompatível com os princípios da imparcialidade e da justiça, crítica essa publicada no jornal Le Monde.

As declarações de Morice, segundo a Corte Europeia, se inseriam num cenário de interesse público, contribuindo para o debate sobre questão de grande repercussão social, atraindo significativa atenção dos meios de comunicação, o que exigia maior amplitude à liberdade de expressão. As bases fáticas das críticas eram suficientes para sustentá-las, não configurando ataque gratuito, visto que os juízes haviam sido afastados do caso. O interesse público estava evidenciado na fiscalização do funcionamento do aparelho judicial, cujos membros, pela sua condição de agentes políticos do Estado, estão submetidos a um padrão de crítica mais flexível do que aquele que diz respeito aos cidadãos comuns. Para a Corte, a 
ingerência no direito de expressão foi desproporcional e incompatível com uma sociedade democrática ${ }^{4}$.

A utilização de expressões além dos limites toleráveis ao debate político implica razão suficiente para medidas restritivas à manifestação crítica.

Foi nesses termos que a Corte decidiu no caso Lindon, Otchakovsky-Laurens and July v. France (21279/02 and 36448/02), que escreveu uma novela intitulada "Le procès de Jean-Marie Le Pen", referindo-se ao presidente da Frente Nacional, um partido político francês de extrema direita. A história era baseada em fatos reais, mas com o acréscimo de elementos ficcionais, e contava o desenrolar do julgamento de um militante da Frente Nacional acusado de homicídio de um jovem de origem africana e que admitiu que o crime foi motivado por racismo. O texto abertamente responsabilizava a Frente Nacional e Le Pen pelo crescimento de discriminações de caráter racista na Europa ${ }^{5}$.

$\mathrm{O}$ autor e o editor foram condenados pela Justiça francesa por danos difamatórios.

O Tribunal Europeu considerou que as passagens ofensivas do texto nomearam a Frente Nacional e Le Pen e que refletiam o próprio pensamento do seu autor, que não contara a história distanciando-se de suas concepções ideológicas. Houve evidente intenção de estigmatizar um oponente (qualificado como "chefe de uma gangue de assassinos") com força suficiente para incitar a violência e o ódio além dos limites admissíveis do debate político. A condenação pela jurisdição nacional, por tais razões, foi amparada em motivação relevante, suficiente e proporcional.

Percebe-se, portanto, que, nos casos envolvendo liberdade de expressão e discurso de ódio, a Corte Europeia vem aplicando, como critério decisório, a regra da medida necessária numa sociedade democrática ${ }^{6}$. A ingerência no direito de expressar ideias e opiniões, ainda que imbuídas de certa hostilidade, somente é justificável diante de circunstâncias que revelam uma necessidade social imperativa, o que confere uma margem limitada à interferência. A

\footnotetext{
${ }^{4}$ Em outra oportunidade, no caso A. v. The United Kingdom (35373/97), a Corte assinalou que a liberdade de expressão é essencial para a função de parlamentares, sendo, por isso, exigíveis fortes razões para interferência.

5 Acerca do combate ao racismo e à xenofobia, o Conselho da União Europeia emitiu a Decisão Marco 2008/913/JAI que, ao instigar os Estados Membros a adotarem medidas sancionadoras de incitação pública à violência e ao ódio, prevê inclusive a responsabilização de pessoas jurídicas que tenham se tornado instrumento para a prática de tais atos. Nesse sentido, confira-se julgado proferido pela Corte Europeia em Delfi AS v. Estonia (64569/09), que envolveu a condenação de empresa proprietária de portal de notícias, no qual foram postados comentários injuriosos e ameaças direcionadas a terceiro, permanecendo on line durante seis semanas.

6 Vide, ainda, os seguintes julgados aplicando esse mesmo critério decisório: Fressoz and Roire v. France (29183/95), Mouvement Raëlien v. Switzerland (16345/06) e Vona v. Hungray (35943/10).
} 
apreciação jurisdicional, nesses termos, não é infensa a um certo grau de subjetividade, notadamente na atividade interpretativa de cada caso, visto que a apreensão a respeito do suporte circunstancial fica submetida à carga pessoal do julgador.

Para que seja estabelecida uma linha comparativa, cumpre, na sequência, averiguar o padrão decisório acolhido pela Corte Interamericana.

\section{REGRA DECISÓRIA APLICADA PELA CORTE INTERAMERICANA DE DIREITOS HUMANOS}

Ao narrar criticamente a história da América Latina desde a chegada dos navegantes europeus até os anos 1970, Eduardo Galeano (2013, p. 18) expõe de forma monumental todo o processo de violação de direitos que assolou a região durante séculos. No curso dos tempos, afirma o escritor uruguaio, "perdemos até o direito de nos chamarmos 'americanos"”, nomenclatura autorreferenciada pelos nativos da América do Norte.

As ditaduras militares instaladas em países como Brasil, Chile, Argentina, Uruguai, Paraguai e Bolívia protagonizaram um contexto de retração sistemática dos direitos fundamentais do cidadão, caracterizado pela violência institucionalizada e legitimada pelo próprio Estado.

A ascensão dos militares ao poder, apoiada por setores sociais convervadores, decorreu do temor de disseminação de governos comunistas na região, gerado pelo êxito da revolução cubana liderada por Fidel Castro, que derrubou o governo de Fulgencio Batista em 1959. Para manter íntegro o controle do Estado e com isso evitar movimentos de boicote pelos opositores ao regime, foi montada toda uma estrutura repressiva orquestrada dos quartéis.

A retomada da soberania popular ocorreu a partir dos anos 1980, quando a pressão pela reabertura do processo político levou a um esgotamento do aparato repressivo e iniciou-se a consolidação de um constitucionalismo democrático, que passou a reger o destino da região.

Nesse contexto de realinhamento democrático, é importante assinalar a normatividade transnacional da Convenção Americana sobre Direitos Humanos, que entrou em vigor em 18 de julho de 1978, e de outros documentos interamericanos de mesma natureza.

A Convenção foi redigida pelos delegados estatais no âmbito da Conferência Especializada Interamericana sobre Direitos Humanos, realizada em San José da Costa Rica, em 22 de novembro de 1969. Sua vigência teve marco inicial após o depósito do décimo 
primeiro instrumento de ratificação.

As normas convencionais representam a culminância de um processo iniciado após o fim da Segunda Guerra Mundial, quando representantes dos países das Américas se reuniram no México e decidiram que deveria ser redigido um instrumento destinado a afirmar e proteger os direitos humanos.

O sistema de tutela desses direitos se concretiza através da Comissão Interamericana de Direitos Humanos e da Corte Interamericana de Direitos Humanos.

A primeira emite suas conclusões acerca de violação a direitos previstos na Convenção na forma de recomendações aos Estados Partes, que podem optar por cumpri-las ou ignorá-las (CERNA, 1997, p. 749). Se as recomendações para o resguardo dos direitos tutelados restarem ineficazes, após esgotados os procedimentos frente à Comissão, o caso poderá ser submetido à Corte Interamericana, que, no exercício da função jurisdicional, decidirá de modo impositivo e irrecorrível aos Estados aderentes, conforme previsto no art. 61 da Convenção.

$\mathrm{O}$ art. $1^{\circ}, \S^{\circ}$, da Convenção assegura o respeito aos direitos e liberdades nela reconhecidos, garantindo ao indivíduo o pleno exercício desses direitos e liberdades sem discriminação por motivo de raça, cor, sexo, idioma, religião, opinião política ou de qualquer outra natureza, origem nacional ou social, posição econômica, nascimento ou qualquer outra condição social.

A honra e a dignidade da pessoa humana têm sua tutela prevista no art. $11, \S 1^{\circ}$, da Convenção.

No que se refere ao direito à liberdade de expressão, que comumentemente é ponderado nos casos que envolvem discurso discriminatório, a Convenção consigna, no seu art. $13, \S 1^{\circ}$, que tal direito abrange a liberdade de buscar, receber e difundir informações e ideias de toda natureza por qualquer meio comunicativo (verbal, escrito, impresso, artístico, etc.). O $\S 2^{\circ}$ do referido dispositivo realça os requisitos à responsabilização ulterior do uso abusivo do direito à liberdade de expressão: deve haver previsão legal e deve ser necessária para assegurar o respeito aos direitos ou à reputação das demais pessoas ou à proteção da segurança nacional, da ordem pública, da saúde ou da moral públicas. O $\$ 5^{\circ}$ diz que a legislação dos Estados Membros deve vedar a apologia ao ódio nacional, racial ou religioso que configure incitação à discriminação, à hostilidade, ao crime ou à violência.

A Convenção Interamericana contra o Racismo, a Discriminação Racial e Formas Conexas de Intolerância realça a necessidade dos Estados de se comprometerem a prevenir, 
eliminar, proibir e sancionar atos e manifestações que envolvam racismo, discriminação e formas similares de agressão à alteridade, tais como a publicação, a circulação ou disseminação de qualquer material que defenda, promova ou incite ao ódio.

A Carta Democrática Interamericana, documento que reafirma a tutela aos direitos humanos na normatização transnacional das Américas, prescreve o respeito à liberdade de expressão como um dos componentes fundamentais do exercício da democracia, ao mesmo tempo em que impõe a necessidade de eliminação de todas as formas de discriminação (arts. $4^{\circ}$ e $\left.9^{\circ}\right)$.

Por fim, o sistema protetivo é integrado pela Declaração de Princípios sobre Liberdade de Expressão, da Comissão Interamericana de Direitos Humanos, que, na sua abertura (Princípio 1), assinala que a livre manifestação de ideias e opiniões é requisito indispensável à existência de uma sociedade democrática, vedando restrições e obstáculos ao livre fluxo informativo (Princípio 5), considerado imprescindível à pluralidade e à diversidade no ambiente sociológico (Princípio 12).

O marco inicial pelo qual a Corte Interamericana de Direitos Humanos passou a analisar o direito à liberdade de expressão foi a Opinião Consultiva 5/85, solicitada pelo governo da Costa Rica, que assinala o conteúdo e os limites desse direito (CANO, 2011, p. 130). Os fundamentos expostos nesse ato opinativo passaram a orientar as decisões da Corte abrangendo a temática do direito à liberdade de expressão.

Quando há injusta restrição à expressão, segundo assinalado pelo Tribunal, a infringência não se limita ao direito do indivíduo, mas alcança igualmente o direito de todos de receber informações e ideias. Disso ressalta a dupla dimensão do direito protegido pelo art. 13 da Convenção: de um lado, na dimensão individual, tutela o cidadão de manifestar seu pensamento, compreendendo o direito de falar, escrever e de utilizar qualquer meio apto para difundi-lo e fazê-lo chegar ao maior número de destinatários; de outro, na sua vertente social, resguarda o direito da coletividade de receber qualquer informação e de conhecer a expressão do pensamento alheio, abrangendo o intercâmbio de ideias e informações de forma massiva. Não é por outro motivo que Dworkin (2012, p. 485) afirma que a tutela do direito à liberdade de expressão do indivíduo implica também a proteção do direito de audiência dos demais. O direito de escutar, nesse sentido, é "parasitário" do direito de se expressar.

Delineando um critério decisório para a legitimidade de medidas restritivas, a Opinião Consultiva 5/85 assinala que tais medidas, à vista do que dispõe o art. 13 da Convenção 
Americana, devem ser direcionadas a satisfazer um interesse público imperativo, a ser verificado segundo objetivos coletivos ${ }^{7}$.

Abrindo um canal de interlocução com a jurisprudência da Corte Europeia, concretizando o fenômeno de diálogo transregional ${ }^{8}$, restou consignado que o juízo restritivo do exercício do direito à liberdade de expressão deve estar vinculado às necessidades legítimas da sociedade e das instituições democráticas.

A dimensão dúplice do direito à liberdade de expressão guiou a decisão da Corte no caso Ivcher Bronstein vs. Peru, em julgado proferido em 06 de fevereiro de 2001.

Os fatos analisados envolveram Baruch Ivcher Bronstein, proprietário de um canal televisivo no Peru. Ele nasceu em Israel, mas adquiriu a cidadania peruana mediante processo de naturalização. Num dos programas da emissora, foram transmitidas reportagens relacionadas com o governo do então presidente Alberto Fujimori. No ano de 1997, o Poder Executivo do Peru expediu decreto regulamentando a Lei de Nacionalidade e estabeleceu a possibilidade de cancelamento da nacionalidade de peruanos naturalizados. Na sequência dos fatos, foi tornada sem efeito a nacionalidade conferida ao senhor Ivcher, o que ocasionou o cancelamento da sua condição de acionista majoritário da empresa de comunicação.

A Corte Interamericana, ao apontar a ocorrência de violação ao art. 13 da Convenção, considerou que a exclusão do demandante do controle acionário, implementada pelo Estado peruano, restringiu não apenas o direito do senhor Ivcher de fazer circular notícias, ideias e opiniões (dimensão individual do direito à liberdade de expressão), mas igualmente atingiu o direito de toda a coletividade de receber informações (dimensão social), obstruindo sua liberdade de fazer opções políticas e de se desenvolver de maneira plena como sociedade democrática.

A regra decisória igualmente restou aplicada no caso Herrera Ulloa vs. Costa Rica, em julgado proferido pela Corte Interamericana em 02 de julho de 2004.

O periódico “La Nación”, da Costa Rica, publicou diversos textos escritos por Mauricio Herrera Ulloa, cujo conteúdo supostamente consistia em uma reprodução parcial de reportagens da imprensa belga que atribuíam ao diplomata Félix Przedborski o cometimento de graves ilícitos. Demandados judicialmente por delito de difamação, Ulloa e o periódico foram

\footnotetext{
7 A compatibilidade da restrição à liberdade de expressão com a Convenção Americana justifica-se numa necessidade social imperiosa (YLARRI, 2015, p 178).

${ }^{8} \mathrm{O}$ diálogo transregional caracteriza-se pela busca de referências a soluções empregadas com êxito em casos
} 
condenados ao pagamento de multa e indenização por danos morais.

Para a Corte, há um consenso nos diferentes sistemas regionais de proteção aos direitos humanos no que se refere ao papel essencial da liberdade de expressão na consolidação e dinâmica de uma sociedade democrática. Em que pese sua função primordial na estrutura social, não se trata de um direito absoluto, visto que está submetido a restrições, que se manifestam através de responsabilização ulterior pelo exercício abusivo, mas limitadas somente ao que for estritamente necessário.

No caso concreto, o senhor Ulloa expressara opinião revestida de interesse público. O debate sobre questões dessa natureza reduz a margem à imposição de medidas restritivas, principalmente quando as críticas são dirigidas a funcionários públicos, expostos, pela sua própria condição, a um escrutínio público mais ampliado do que aquele que alcança o cidadão comum.

À vista dessas premissas, a Corte decidiu que o ato condenatório infligido ao senhor Ulloa excedeu os marcos contidos no art. 13 da Convenção, não configurando uma restrição imperiosa em uma sociedade democrática.

A imperatividade do interesse público em questões que envolvem o fluxo de informações em uma sociedade pluralista e democrática, notadamente quando decorrente de opinião do emissor, foi analisada no caso Usón Ramírez vs. Venezuela, decidido em 20 de novembro de 2009, envolvendo demandante que fora condenado pela jurisdição venezuelana por declarações críticas em rede televisiva a respeito das forças armadas do país. Para a Corte, além de a manifestação ter relação direta com o interesse de toda a coletividade, ela estava pautada em uma opinião do emissor. Como se situa no campo das ideias e convicções, a opinião do cidadão não é passível de ser considerada nem verdadeira nem falsa, o que impede que seja objeto de sanção por parte do Estado, sob pena de violação do art. 13 da Convenção.

Percebe-se que, subjacente a esse entendimento, há uma ideia que extravasa a esfera individual. A ameaça de o cidadão sofrer penalidade por emitir opinião teria o efeito prático de inibir sua manifestação, vindo isso em prejuízo da coletividade de conhecê-la e julgá-la por seus próprios meios, extraindo desse processo cognitivo, plural e democrático, suas conclusões. Pedra angular numa sociedade democrática, a liberdade de expressão constitui, no

similares em outros sistemas regionais (BARRERA; CÁRDENAS, 2012, p. 188). 
entendimento da Corte, condição essencial para que esteja suficientemente informada ${ }^{9}$.

A presença de interesse público vem sendo ponderada sistematicamente pela Corte na avaliação da necessidade, ou não, de ingerência no direito de expressão, sendo ilustrativo o Caso Ricardo Canese vs. Paraguai, julgado em 31 de agosto de 2004.

Nas eleições presidenciais do Paraguai no ano de 1993, o candidato Ricardo Canese questionou a idoneidade moral de seu oponente Juan Carlos Wasmosy, que era presidente do consórcio do projeto hidroelétrico de Itaipu. Para Canese, o adversário repassava dividendos ao ditador Strossner. Por tais afirmações, publicadas na imprensa, Canese foi condenado pela jurisdição paraguaia a dois meses de prisão e ao pagamento de multa.

Enfatizando as motivações decisórias aplicadas no caso Herrera Ulloa, a Corte Interamericana assinalou que as pessoas que têm atuação no debate que envolve a coletividade dos cidadãos se expõem de modo voluntário a um exame público mais exigente e, por isso, são mais vulneráveis a críticas, pois suas atividades não se circunscrevem à esfera privada. Declarações feitas no contexto de uma campanha eleitoral despertam a atenção pública, até porque são emitidas de maneira mais intensa e dinâmica, em consonância, inclusive, com o princípio do pluralismo democrático. Dadas as circunstâncias do caso, inexistiu interesse social imperativo que justificasse a sanção penal imposta ao candidato presidencial.

A imperatividade do interesse público no exercício do direito à liberdade de expressão, segundo a Corte, contempla a proteção do direito de acesso à informação sob controle das autoridades estatais, que igualmente abrange as dimensões individual e social. Nesse contexto, o Estado está sujeito aos princípios da publicidade e transparência na gestão pública, o que permite aos cidadãos o controle democrático de pessoas e instituições envolvidas na consecução de políticas que dizem respeito à toda a sociedade. A fiscalização da cidadania, com o acesso à informação, instrumentaliza a participação democrática. Cumpre ao Estado minimizar as restrições à circulação de informes e opiniões e equilibrar, na medida das possibilidades circunstanciais, a participação das distintas informações no debate público, resguardando, com isso, a diversidade formativa e informativa ${ }^{10}$.

\footnotetext{
${ }^{9}$ Caso La Última Tentación de Cristo (Olmedo Bustos y Otros) vs. Chile, julgado em 05 de fevereiro de 2001.

${ }^{10}$ Vide, a respeito, a decisão proferida em 02 de maio de 2008, envolvendo as partes Kimel vs. Argentina, em que o Tribunal Interamericano julgou o caso do escritor daquele país que fora condenado pelo crime de calúnia por escrever e publicar um livro investigativo sobre o massacre de San Patrício, ocorrido na época da ditadura militar. Confira-se, ainda, o caso Tristán Donoso vs. Panamá, julgado em 27 de janeiro de 2009, em que o advogado demandante havia sido condenado à pena de prisão, por denunciar publicamente o ex-Procurador Geral da Nação pela prática de gravar conversa telefônica com pessoa supostamente envolvida em delito de
} 
Essas premissas integraram a decisão proferida pela Corte no caso Claude Reyes e outros vs. Chile, em 06 de setembro de 2006. Os demandantes haviam postulado informações ao Comitê de Inversões Estrangeiras do Chile sobre uma empresa envolvida em projeto de desflorestamento e industrialização, que seria realizado em uma região daquele país e que poderia causar nocividade ao meio ambiente e ao desenvolvimento sustentável. A instituição chilena negou o pedido, sem elencar motivos válidos de acordo com a legislação interna.

O impacto ambiental decorrente do empreendimento poderia gerar ampla repercussão e grande discussão pública, de modo que o acesso às informações não seria passível de obstaculização a quem se mostrasse interessado.

Em razão disso e realçando que o direito amparado pelo art. 13 da Convenção Interamericana sustenta-se não apenas na expressão do próprio pensamento, mas também no direito de buscar, receber e difundir informações e ideias de toda índole, a Corte julgou que a restrição não fora orientada a satisfazer um interesse público imperioso, que, bem ao contrário, situava-se justamente na reivindicação direcionada à instituição do Estado.

Embora não se tenha encontrado no histórico jurisprudencial da Corte um debate abertamente envolvendo discurso de ódio e interesse público, é difícil conceber, num ambiente socialmente pluralista, uma composição prática entre esses dois conceitos, visto que representam significados ontologicamente inconciliáveis. Como essa espécie de discurso tem como pressuposto uma concepção ideológica ofensivamente discriminatória, não se vislumbra compatibilidade possível com o interesse da coletividade numa sociedade democrática, princípio reiteradamente afirmado pela Corte em suas decisões relacionadas aos casos de violação ao direito à liberdade de expressão.

lavagem de dinheiro. Para a Corte, no caso decidido, o princípio da "equidade deve reger o fluxo informativo". 


\section{CONCLUSÃO}

À vista do que restou exposto acima, é possível afirmar que tanto quanto a regra decisória aplicada pelo órgão de jurisdição prestigiar uma maior intervenção no direito à liberdade de expressão, tanto menor será a admissibilidade à retórica da intolerância, da qual ressalta o discurso de ódio como sua forma mais perniciosa à higidez dos princípios da pluralidade e da alteridade que caracterizam a sociedade na pós-modernidade.

A Corte Europeia de Direitos Humanos, ao autorizar restrições ao direito à liberdade de expressão desde que seja medida necessária em uma sociedade democrática, coíbe de modo enfático a ocorrência de discurso de ódio. A aferição da necessidade fica condicionada às circunstâncias de cada caso, o que não imuniza, nesse processo interpretativo, a subjetividade do julgador, tornando possível a ocorrência de decisões díspares para situações com traços fáticos caracteristicamente similares. Percebe-se que a Corte procura tutelar a discussão de questões que envolvam o interesse da coletividade como um todo, tal como sucede com o debate de natureza política. Nesse contexto, não se concebe um exacerbamento do direito do indivíduo manifestar o que bem entende, a ponto de incitar a intolerância. No diálogo intercultural que tipifica o continente europeu, e que constitui um de seus pilares socialmente estruturantes, o indivíduo deve nortear suas ações com o devido respeito à alteridade. A jurisprudência da Corte Europeia, à vista desses fundamentos, permite maior limitação à liberdade de expressão, em razão de uma menor aceitabilidade ao discurso de ódio.

A despeito da terminologia diversificada, a regra decisória da impositividade do interesse público, em casos que dizem respeito à retração da liberdade de expressão, aplicada pela Corte Interamericana de Direitos Humanos, não destoa, em essência, daquela acolhida pela Corte Europeia. No sistema protetivo dos direitos humanos das Américas não há uma inquestionabilidade do direito de expressão do indivíduo, pois ele está condicionado à preservação do equilibrado convívio social e à observância de valores coletivos. Em que pese a inexistência de decisão específica acerca do discurso de ódio no histórico jurisprudencial da Corte Interamericana, sintoma, talvez, da maior homogeneidade cultural dos povos que habitam a região, denota-se, pela primazia conferida ao interesse público, uma maior possibilidade de intervenção no direito à liberdade de expressão, o que, via de consequência, 
diminui a permissibilidade à retórica de ódio.

Percebe-se uma clara identidade entre as regras de decisão aplicadas pela Corte Europeia e pela Corte Interamericana, que se estende inclusive ao nível de admissibilidade ao discurso de ódio, que, em ambas as jurisdições, é bastante limitado.

\section{REFERÊNCIAS BIBLIOGRÁFICAS}

ARISTÓTELES. Retórica. Madrid: Alianza Editorial, 2007.

BARRERA, Tania G. Vivas; CÁRDENAS, Jaime A. Cubides. Diálogo judicial transnacional en la implementación de las sentencias de la Corte Interamericana. Entramado [on line], v. 8, n. 2, julio-diciembre 2012, p. 184-204.

CANO, José Antonio Arcila. La libertad de expresión en la jurisprudencia de la Corte Interamericana (1985-2009). Forum - Revista del Departamento de Ciencia Política, Universidad Nacional, Medellín, n. 1, enero-julio 2011, p. 113-146.

CERNA, Christina M. International law and the protection of human rights in the interamerican system. Houston Journal of International Law, v. 19, 1997, p. 731-756.

DZELME, Inta. Psychological effects of hate crime - Individual experience and impact on community (Attacking who I am). Latvian Centre for Human Rights, 2008.

DWORKIN, Ronald. Una cuestión de principios. Buenos Aires: Siglo Ventiuno Editores, 2012.

GALEANO, Eduardo. As veias abertas da América Latina. Porto Alegre: L\&PM Pocket, 2013.

MILL, John Stuart. Sobre a liberdade e A sujeição das mulheres. São Paulo: Pinguin Clássicos Companhia das Letras, 2017.

ROSSATTO, Rosana; GUARDI, Elbio Nelson Cardoso. A ontogênese do ódio. Diaphora Revista da Sociedade de Psicologia do Rio Grande do Sul, v. 17, 2017, p. 09-13.

SILVA, Rosane Leal da; FAVERA, Rafaela Bolson Dalla. Estudo do caso Klayman v. Zuckerberg and Facebook: da liberdade de expressão ao discurso do ódio. Revista Brasileira de Direito, v. 13, n. 2, mai.-ago. 2017, p. 273-292.

VALDÉS, Roberto L. Blanco. La construcción de la libertad: apuntes para una historia del constitucionalismo europeo. Madrid: Alianza Editorial, 2010.

VOLTAIRE. Tratado sobre a tolerância: por ocasião da morte de Jean Calas (1763). Porto Alegre: L\&PM, 2017. 
YLARRI, Juan Santiago. La libertad de expresión en la jurisprudencia de la Corte Interamericana de Derechos Humanos. Cuadernos Manuel Giménez Abad, n. 10, diciembre 2015, p 172-184. 